\title{
Activity of autotrophic Fe(II)-oxidizing denitrifiers in freshwater lake sediments
}

Yunmeng Pang a, b, Jian-Long Wang b, Shengjie Li a , Guodong Ji a, *

a Key Laboratory of Water and Sediment Sciences, Ministry of Education, Department of Environmental Engineering, Peking University, Beijing 100871, China

${ }^{b}$ Laboratory of Environmental Technology, INET, Tsinghua University, Beijing 100084, China

*Corresponding author. Tel.: +86 10 62758069; fax: +86 10 62758069. E-mail address: jiguodong@pku.edu.cn 


\section{Supporting Information}

S1 Calculating methods of the relative contribution of biological Fe(II)-oxidizing denitrification to total denitrification.

Table S1 Composition of inorganic medium.

Table S2 Composition of trace element solution.

Table S3 Physical and chemical properties of the lake sediments.

Table S4 The molar ratios of $\mathrm{Fe}(\mathrm{I})$ oxidation rates and nitrate reduction rates in different cycles of the long-term incubations.

Fig. S1 Contents of different Fe forms in the sediment samples of Hongze Lake and Nansihu Lake.

Fig. S2 Changes of nitrate reduction rates in the long-term incubations of Hongze Lake (a) and Nansi Lake (b) samples.

Fig. S3 Sulfide and sulfate concentrations during long-term incubations of Hongze Lake (a) and Nansi Lake (b) samples.

Fig. S4 Significant differences of nirS genera among different incubations $(\mathrm{P}<0.05)$ 


\section{S1 Calculating methods of the relative contribution of biological Fe(II)-oxidizing denitrification to total denitrification.}

The relative contribution of biological Fe(II)-oxidizing denitrification to total denitrification can be calculated by how much biological Fe(II) was used compared to the theory:

$$
\begin{gathered}
P=F e(\mathrm{II})_{\text {biological }} / F e(\mathrm{II})_{\text {theoretical }} \\
F e(\mathrm{II})_{\text {biological }}=\mathrm{Fe}(\mathrm{II})_{\text {total }}-\mathrm{Fe}(\mathrm{II})_{\text {chemical }}
\end{gathered}
$$

where $P$ is the estimated relative contribution; $\mathrm{Fe}(\mathrm{II})_{\text {biological }}$ is the amount of $\mathrm{Fe}$ (II) used via biological Fe(II)-oxidizing denitrification in microbially active $\mathrm{NO}_{2}{ }^{-}+\mathrm{Fe}(\mathrm{II})$ or $\mathrm{NO}_{3}{ }^{-}+\mathrm{Fe}(\mathrm{II})$ treatments; $\mathrm{Fe}(\mathrm{II})_{\text {theoretical }}$ is the theoretical amount of $\mathrm{Fe}$ (II) used via biological Fe(II)-oxidizing denitrification; $\mathrm{Fe}(\mathrm{II})_{\text {total }}$ is the total amount of $\mathrm{Fe}$ (II) used in microbially active treatments; $\mathrm{Fe}$ (II) chemical $_{\text {is }}$ the amount of $\mathrm{Fe}$ (II) used via chemical reaction in microbially active treatments.

In nitrite reduction treatments, Since the $\mathrm{N}_{2} \mathrm{O}$ concentration was less than $4.3 \%$ of the total $\mathrm{N}$ input at the end of the incubations, we assumed that $\mathrm{NO}_{2}{ }^{-}$to $\mathrm{N}_{2}$ was the dominant process:

$$
6 \mathrm{Fe}^{2+}+2 \mathrm{NO}_{2}^{-}+14 \mathrm{H}_{2} \mathrm{O} \rightarrow 6 \mathrm{Fe}(\mathrm{OH})_{3}+\mathrm{N}_{2(\mathrm{~g})}+10 \mathrm{H}^{+}
$$

Since the $\mathrm{NO}_{2}^{-}$reduced is $1(1 \mathrm{mmol}), \mathrm{Fe}$ (II) ${ }_{\text {theoretical }}$ is $3 . \mathrm{Fe}$ (II) ${ }_{\text {total }}$ is the total amount of $\mathrm{Fe}$ (II) used in microbially active $\mathrm{NO}_{2}^{-}+\mathrm{Fe}(\mathrm{II})$ treatments; the maximum of $\mathrm{Fe}(\mathrm{II})_{\text {chemical }}$ should be the $\mathrm{Fe}$ (II) used in Sterile $+\mathrm{NO}_{2}{ }^{-}+\mathrm{Fe}(\mathrm{II})$ (no cells) treatments.

In nitrate reduction treatments, the dominant process of $\mathrm{Fe}(\mathrm{II})$-oxidizing denitrification is as:

$$
10 \mathrm{Fe}^{2+}+2 \mathrm{NO}_{3}{ }^{-}+24 \mathrm{H}_{2} \mathrm{O} \rightarrow 10 \mathrm{Fe}(\mathrm{OH})_{3}+\mathrm{N}_{2(\mathrm{~g})}+18 \mathrm{H}^{+}
$$

Since the $\mathrm{NO}_{3}{ }^{-}$reduced is $1(1 \mathrm{mmol}), \mathrm{Fe}$ (II) ${ }_{\text {theoretical }}$ is $5 . \mathrm{Fe}$ (II) ${ }_{\text {total }}$ is the total amount of $\mathrm{Fe}$ (II) used in microbially active $\mathrm{NO}_{3}{ }^{-}+\mathrm{Fe}(\mathrm{II})$ treatments.

$$
F e(\mathrm{II})_{\text {chemical }}=\mathrm{Fe}(\mathrm{II})_{\text {chemical }}\left(\mathrm{NO}_{3}{ }^{-} \rightarrow \mathrm{NO}_{2}^{-}\right)+F e(\mathrm{II})_{\text {chemical }}\left(\mathrm{NO}_{2}{ }^{-} \rightarrow \mathrm{N}_{2}\right)
$$


In the Sterile $+\mathrm{NO}_{3}{ }^{-}+\mathrm{Fe}(\mathrm{II})$ treatments, the concentrations of $\mathrm{NO}_{3}{ }^{-}$and $\mathrm{Fe}(\mathrm{II})$ remained almost unchanged in the two lake samples, indicating that no chemical reactions occurred between $\mathrm{NO}_{3}{ }^{-}$and $\mathrm{Fe}(\mathrm{II})$. Thus, $\mathrm{Fe}(\mathrm{II})$ chemical $\left(\mathrm{NO}_{3}{ }^{-} \rightarrow \mathrm{NO}_{2}^{-}\right)$should be 0 . The maximum of $\mathrm{Fe}(\mathrm{II})_{\text {chemical }}$ should be the $\mathrm{Fe}$ (II) used in Sterile $+\mathrm{NO}_{2}^{-}+\mathrm{Fe}$ (II) (no cells) treatments.

Table S1 Composition of inorganic medium

\begin{tabular}{cc}
\hline Inorganic medium composition & Concentration $(\mathrm{g} / \mathrm{L})$ \\
\hline $\mathrm{MgCl}_{2}$ & 0.02 \\
$\mathrm{CaCl}_{2}$ & 0.01 \\
$\mathrm{KH}_{2} \mathrm{PO}_{4}$ & 0.01 \\
$\mathrm{NaHCO}_{3}$ & 0.1 \\
\hline
\end{tabular}

Table S2 Composition of trace element solution

\begin{tabular}{cc}
\hline Trace element solution composition & Concentration $(\mathrm{mg} / \mathrm{L})$ \\
\hline $\mathrm{FeSO}_{4} \cdot 7 \mathrm{H}_{2} \mathrm{O}$ & 0.1 \\
$\mathrm{H}_{3} \mathrm{BO}_{3}$ & 0.03 \\
$\mathrm{MnCl}_{2} \cdot 2 \mathrm{H}_{2} \mathrm{O}$ & 0.12 \\
$\mathrm{CoCl}_{2} \cdot 6 \mathrm{H}_{2} \mathrm{O}$ & 0.12 \\
$\mathrm{NiCl}_{2} \cdot 6 \mathrm{H}_{2} \mathrm{O}$ & 0.024 \\
$\mathrm{ZnCl}_{2}$ & 0.07 \\
$\mathrm{Na}_{2} \mathrm{MoO}_{4} \cdot 2 \mathrm{H}_{2} \mathrm{O}$ & 0.036 \\
$\mathrm{CuSO}_{4} \cdot 5 \mathrm{H}_{2} \mathrm{O}$ & 0.015 \\
\hline
\end{tabular}


Table S3 Physical and chemical properties of lake sediments

\begin{tabular}{cccccccccc}
\hline & $\begin{array}{c}\text { Water } \\
\text { content }\end{array}$ & $\mathrm{pH}$ & $\begin{array}{c}\mathrm{ORP} \\
(\mathrm{mv})\end{array}$ & $\begin{array}{c}\mathrm{TN} \\
(\mathrm{g} / \mathrm{kg})\end{array}$ & $\begin{array}{c}\mathrm{TOC} \\
(\mathrm{g} / \mathrm{kg})\end{array}$ & $\begin{array}{c}\mathrm{C} / \mathrm{N} \\
\mathrm{NH}_{4}^{+}-\mathrm{N}\end{array}$ & $\begin{array}{c}\mathrm{NO}_{3}^{-}-\mathrm{N} \\
(\mathrm{mg} / \mathrm{kg})\end{array}$ & $\begin{array}{c}\mathrm{NO}_{2}-\mathrm{N} \\
(\mathrm{mg} / \mathrm{kg})\end{array}$ & $(\mathrm{mg} / \mathrm{kg})$ \\
\hline Hongze & 33.04 & 8.14 & -129 & 1.09 & 0.98 & 8.99 & 38.24 & 5.48 & 0.23 \\
Lake & & & & & & & & & \\
Nansi & & & & & & & & & \\
Lake & 46.40 & 8.01 & -188 & 2.67 & 3.47 & 12.98 & 302.56 & 13.62 & 0.11 \\
\hline
\end{tabular}

Table S4 The molar ratios of $\mathrm{Fe}$ (II) oxidation rates and nitrate reduction rates in different cycles of the long-term incubations.

\begin{tabular}{|c|c|c|c|c|c|c|c|}
\hline & & Cycle1 & Cycle2 & Cycle3 & Cycle4 & Cycle5 & Cycle6 \\
\hline $\begin{array}{c}\mathrm{Fe}(\text { II }) \\
\text { oxidized }\end{array}$ & $\begin{array}{l}\text { Hongze } \\
\text { Lake }\end{array}$ & \multirow[t]{2}{*}{0.85} & \multirow[t]{2}{*}{0.83} & \multirow[t]{2}{*}{1.59} & \multirow[t]{2}{*}{4.22} & \multirow[t]{2}{*}{4.79} & \multirow[t]{2}{*}{-} \\
\hline (molar ratio) & & & & & & & \\
\hline $\begin{array}{l}\mathrm{NO}_{3}^{-} \\
\text {reduced }\end{array}$ & $\begin{array}{l}\text { Nansi } \\
\text { Lake }\end{array}$ & \multirow[t]{2}{*}{0.58} & \multirow[t]{2}{*}{0.53} & \multirow[t]{2}{*}{0.54} & \multirow[t]{2}{*}{1.46} & \multirow[t]{2}{*}{3.08} & \multirow[t]{2}{*}{3.81} \\
\hline (molar ratio) & & & & & & & \\
\hline
\end{tabular}




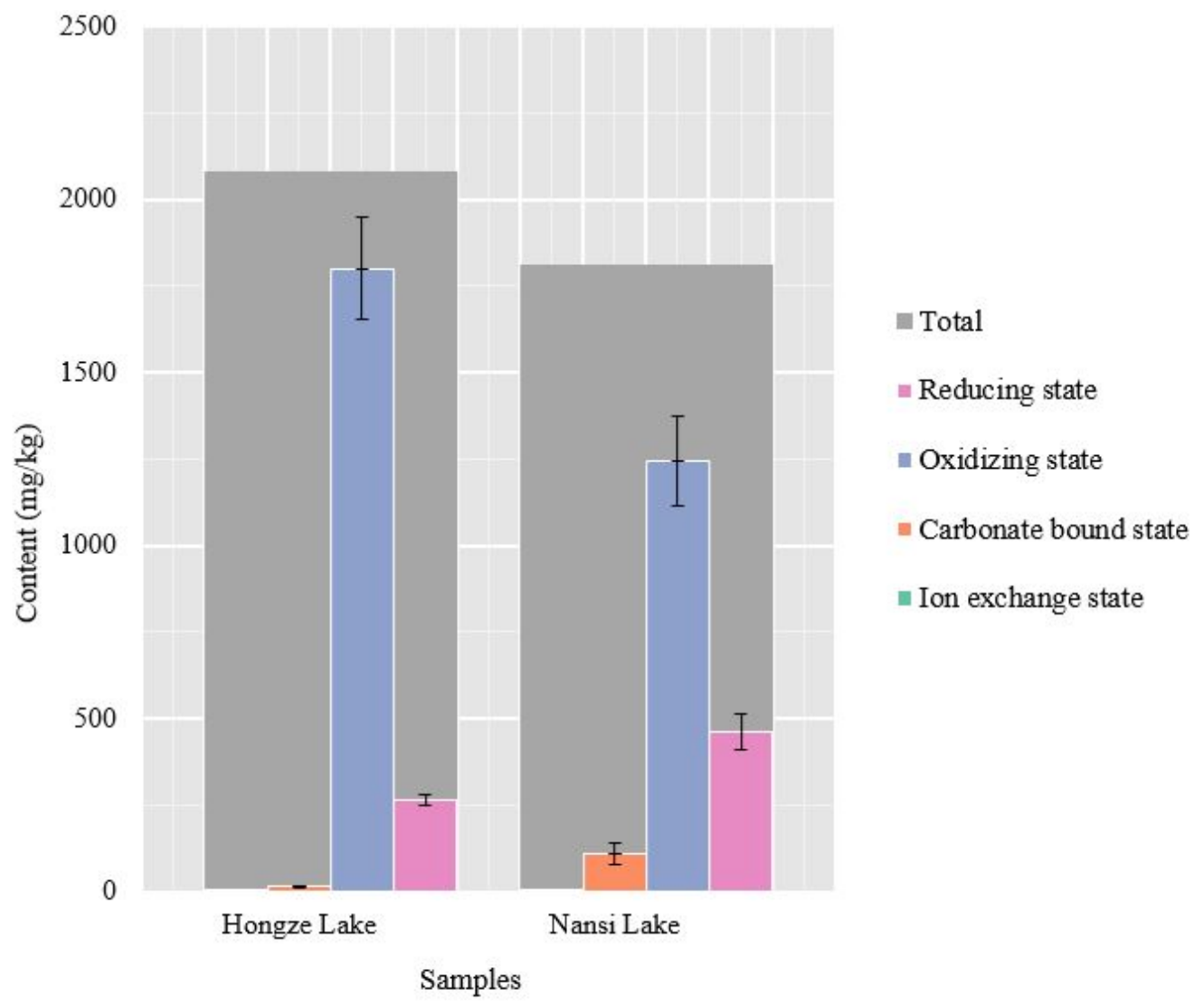

Fig. S1 Contents of different forms of iron in the sediment samples of Hongze Lake and Nansihu Lake 

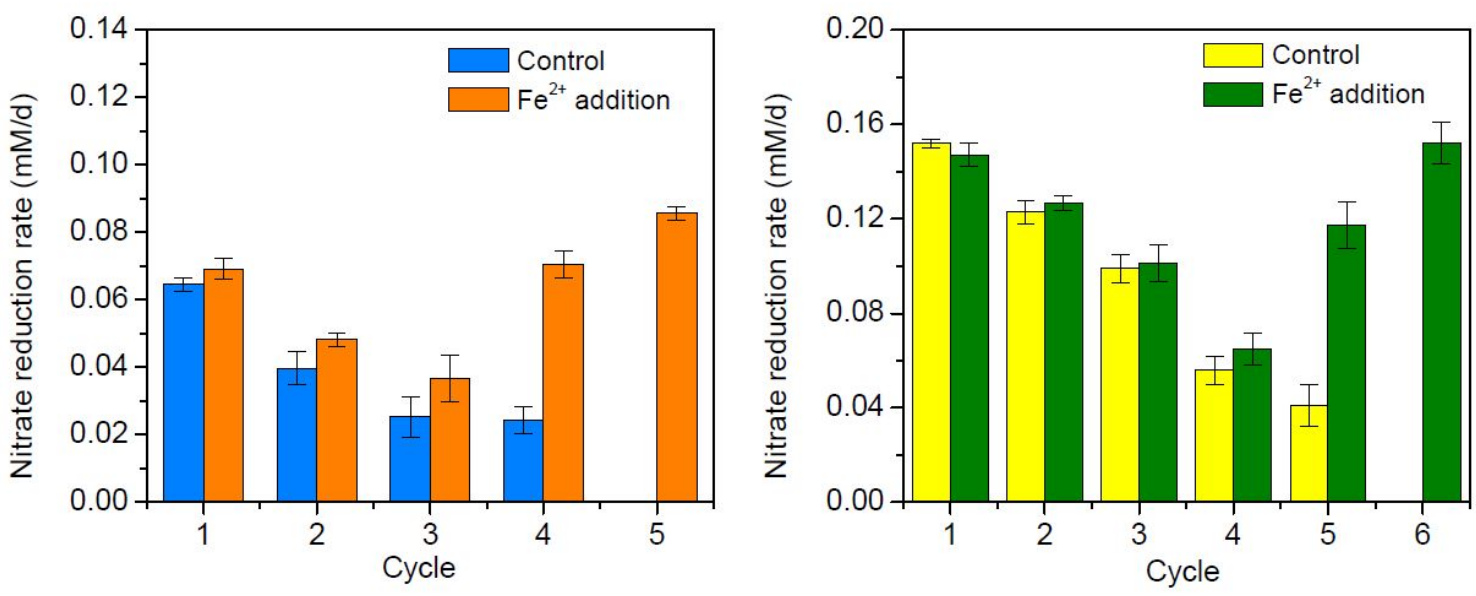

Fig. S2 Changes of nitrate reduction rates in long-term incubations of Hongze Lake (a) and Nansi Lake (b) samples 
(a)

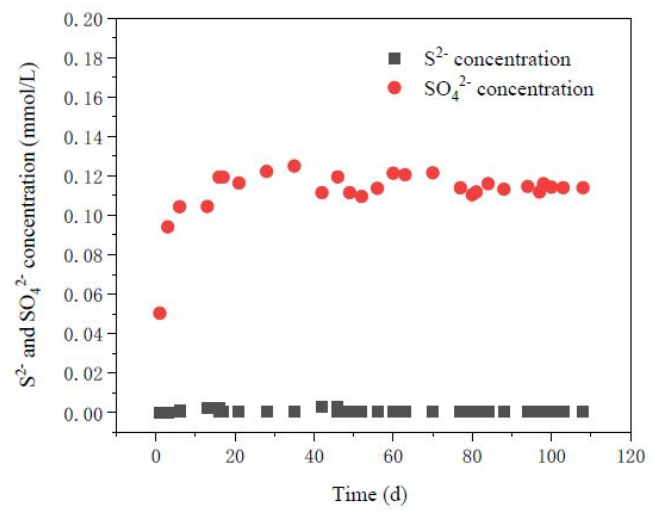

(b)

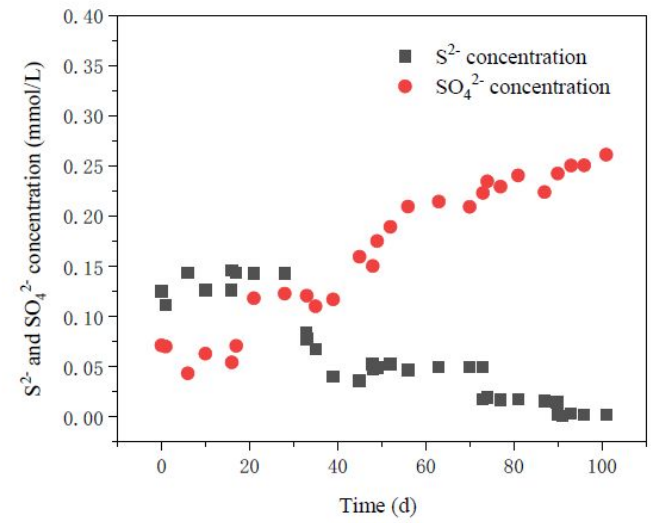

Fig S3. Sulfide and sulfate concentrations during long-term incubations of Hongze Lake (a) and Nansi Lake (b) samples. 

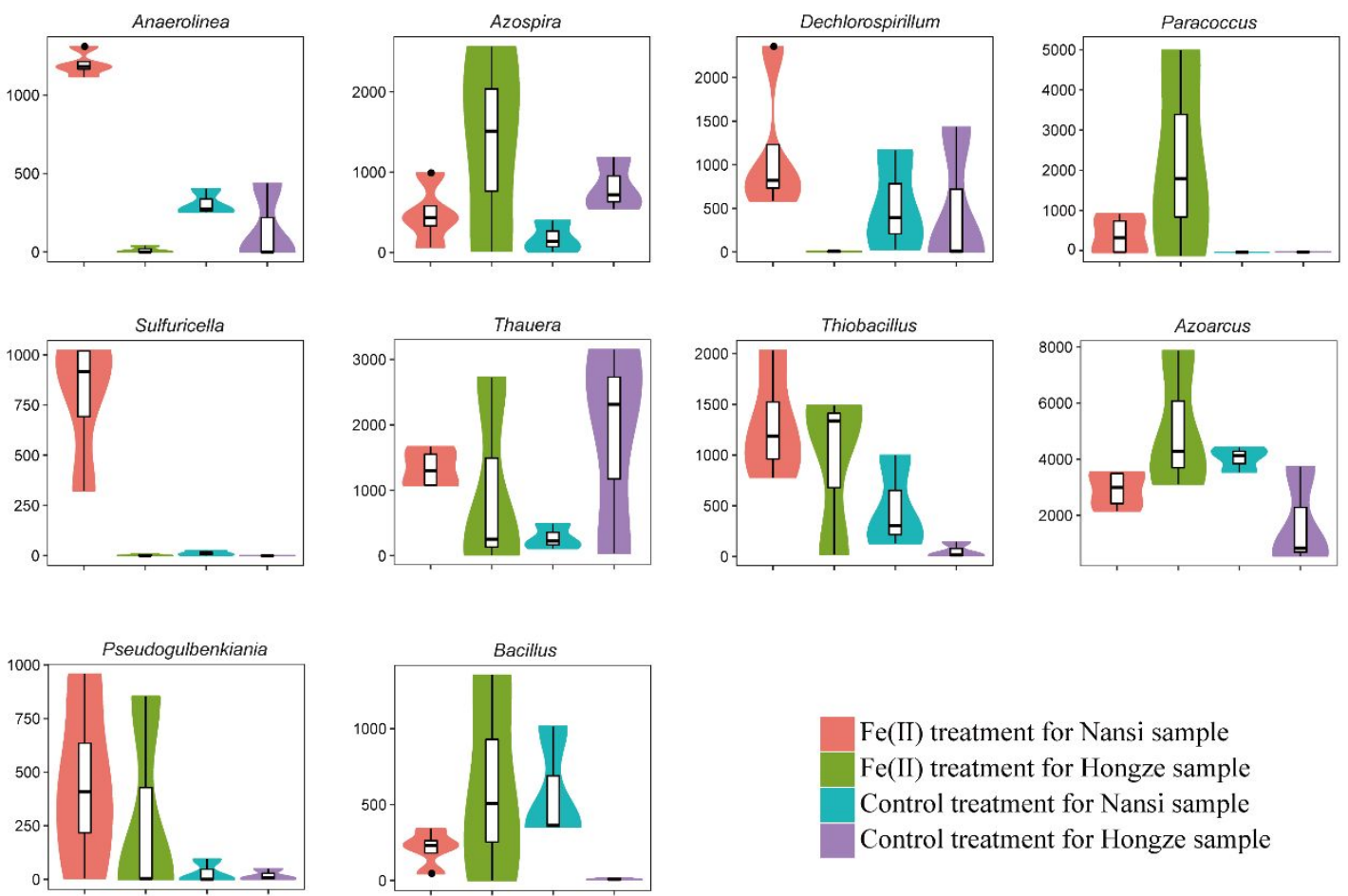

$\mathrm{Fe}(\mathrm{II})$ treatment for Nansi sample

$\mathrm{Fe}(\mathrm{II})$ treatment for Hongze sample Control treatment for Nansi sample

Control treatment for Hongze sample

Fig. S3 Significant differences of nirS genera among different incubations $(P<0.05)$ 